\title{
Regional economic effects of renewable energies - comparing Germany and Japan
}

\author{
Jörg Raupach-Sumiya ${ }^{1 *}$, Hironao Matsubara ${ }^{2}$, Andreas Prahl ${ }^{3},{\text { Astrid } \text { Aretz }^{4} \text { and Steven Salecki }}^{4}$
}

\begin{abstract}
Background: Renewable energy (RE) creates opportunities for sustainable, socioeconomic development of local communities as fossil fuel-based energy imports are substituted with local RE sources. Established methods such as input-output (I/O) analysis face limitations when assessing these regional effects due to insufficient model integration of RE sectors. For Germany, regional value-added modeling based on RE value chain analysis is recognized as a viable alternative approach. The international transferability of this model is tested for the case of Japan.

Methods: The model of regional value-added developed by the Institute of Ecological Economy Research (IÖW model) is adapted to Japan for five representative RE technologies. The estimate of regional value-added for Japan is based on standardized, technology-specific value chain structures with Japan-specific cost and revenue data for individual RE technologies, and applies Japanese statistical sources and tax schemes.

Results: The transferability of the IÖW model to other countries requires modifications to reflect country-specific industry structures, tax codes, and policy frameworks. The comparative analysis between Germany and Japan reveals substantial differences in the economics of individual RE technologies and the distribution of regional value-added. RE has a comparable high potential for regional economic development in Japan but depends largely on local ownership of RE sources.

Conclusions: The IÖW model offers a powerful tool for regional planners and policymakers to analyze and capture the potential of RE for regional economies. Its application for a comparative analysis between countries provides indications to enhance the effectiveness of RE-related policies for regional economic development.
\end{abstract}

Keywords: Renewable energy; Value chain analysis; Regional value-added; Sustainable energy supply; Japan

\section{Background}

Renewable energy (RE) such as solar, wind, hydro, biomass, or geo-thermal power is globally growing into an increasingly important power source for electricity, heating, and transportation, already accounting for $19 \%$ of total global energy consumption in 2012 [1]. This share is expected to rise to $30 \%$ to $45 \%$ in 2050 , backed by fast growing global investment into RE amounting to $\$ 400$ to $\$ 500$ billion annually [2]. The rapid global advance of RE may well lead to a fundamental, structural transformation of national energy systems with far reaching economic, social and ecological consequences, as predominately centralized, rather rigid supply systems are transformed into largely decentralized, flexible ones $[3,4]$. The decentralized

\footnotetext{
* Correspondence: raupach@fcritsumei.ac.jp

'College of Business Administration, Ritsumeikan University, Kyoto, Japan Full list of author information is available at the end of the article
}

and distributed nature of a RE-based energy system leads to questions about the potential of RE deployment for regional economic development. In Germany, widely considered a pioneer in RE, the promise of local job and business creation has been a key motivation for the rapid surge of investment and rapid growth of RE which in 2013 accounted for $25.4 \%$ of Germany's gross electricity consumption [5-8]. Also in Japan, where the Japanese government is promoting RE in response to the disaster at Fukushima Daiichi nuclear power plant, researchers, policy makers, and local communities are turning their attention to the potential of $\mathrm{RE}$ for regional economic development [9-13].

This leads to questions about suitable methods to measure and evaluate possible regional economic effects as a result of the expansion of RE. Breitschopf/Nathani/Resch [14] provide a systematic review of various methodological

\section{黑 Springer}


approaches that analyze the impact of RE on employment and other economic variables on a regional, national, and international level. The review covers more than 30 studies worldwide from 2003 to 2011 and compares them along a set of criteria such as the scope of impacts (e.g., direct, indirect, induced effects), the type of impulses (e.g., investment, trade, household consumption), the required type of input data, or the extent of dynamic effects that are considered (e.g., price and productivity effects, structural changes, scenarios). These modeling approaches are classified into gross models and net models. Net models assess the positive and negative, dynamic impacts of growing RE deployment on the overall economy as well as on non-RE industries. They employ comprehensive macroeconomic approaches such as econometric, general equilibrium, or system dynamic models. Gross models, on the other hand, only capture the positive economic effects within RE-related industries. They typically apply less complex analytical models such as employment factor analysis and focus on individual RE technologies or single regions and countries.

Input-output $(\mathrm{I} / \mathrm{O})$ modeling and related methods such as social accounting matrix or integrated econometric and I/O modeling are well-established, multi-sector approaches to analyze exogenous or policy-induced economic effects across industries on a national and regional level $[15,16]$. As its main strengths, I/O modeling builds on an integrated and consistent methodological framework that breaks down the estimated impacts into finely disaggregated industry sectors and then comprehensively measures direct and induced impacts on output or employment . Due to these advantages, $\mathrm{I} / \mathrm{O}$ analysis has been widely applied also for the evaluation of the gross as well as net economic effects of advanced RE deployment. Examples for I/O studies on a national level are Lehr et al. [17] and O'Sullivan et al. [18] for employment effects of RE in Germany, APPA [19] for Spain, or NISTEP [20] for Japan. On a regional level, examples are Coon [21] for North Dakota, and Allan/McGregor/Swales [22] for Shetland Islands/Scotland.

However, the adoption of I/O modeling for RE on a regional level faces a number of serious obstacles which may compromise the reliability and accuracy of their results [23]. The required quality and sector-specific disaggregation of input data for $\mathrm{I} / \mathrm{O}$ tables is often not available on a regional level such as municipalities or regional districts, and their generation is time-consuming and costly. Alternatively, the derivation of regional $\mathrm{I} / \mathrm{O}$ tables from national statistics tends to compromise data quality such as the applied multipliers and reduces the level of sector disaggregation [24]. Regional I/O tables and the underlying data are often likely to be outdated. Furthermore, the RE industry is usually not yet reflected as an independent sector in the sector-specific structures of I/O models. I/O modeling, therefore, assumes general industry averages for sector-specific input structures, import relations, and employment coefficients that not accurately reflect the structural characteristics of the RE sector [14]. A more accurate $\mathrm{I} / \mathrm{O}$ model would require the integration of the $\mathrm{RE}$ industry as an independent sector based on specific cost and revenue structures of RE-related enterprises.

In order to cope with these limitations, a number of research institutions in Germany such as the Institute for Ecological Economy Research (IÖW), the Institute of Economics at the University of Kassel, the Institute for Applied Material Flow Management (IfaS) at Trier University, or the Institute for decentralized Energy Technologies (IdE) have developed an alternative approach that applies value-added modeling in combination with technology-specific value chain analysis to measure and evaluate the direct regional economic gross effects of specific RE technologies [25-29]. While differing in respect to the covered range of technologies and scope of the value chains, these models capture the complexity of activities along the multi-tiered stages of technologyspecific value chains in the RE industry and are based on a comprehensive set of technology-specific cost, revenue and investment data obtained through extensive enterprise and RE-related project surveys. Regional characteristics of the RE-specific value chains are then integrated into the region-specific analysis of the generated value-added and employment. Thus a high level of reliability of results can be expected from this sophisticated, bottom-up modeling approach. Furthermore, this modeling approach allows for a detailed analysis of the distribution of the generated value-added along the various stages in terms of income, business profit, and regional taxes [23].

A comparative analysis of the results of these studies reveals a high level of consistency and compatibility. They all apply the regional value-adding approach to several municipalities or regional districts and consistently highlight the substantial positive impact of RE for the economic development of these local economies [30]. Also the comparison with the results from I/O-based studies of national employments effects of RE for Germany provides evidence, though limited in scope, about the validity and reliability of the regional value-added modeling approach. The I/O-based study of O'Sullivan et al. [18], which made substantial efforts to integrate RE-specific indicators into their I/O model, estimates that RE provided 378,000 jobs in Germany in 2012, while the study of the IÖW (Hirschl B, Heinbach K, Prahl A, Salecki S, Schröder A, Aretz A, Weiß : Wertschöpfung durch Erneuerbare Energien Ermittlung der Effekte auf Länder- und Bundesebene, forthcoming), based on regional value-added modeling, results in a comparable figure of 344,000 RE-related jobs. While further validation of the regional value-added 
modeling approach by means of a rigorous and systematic methodological comparison is still wanted, the above elaborations lead to the conclusion that $\mathrm{I} / \mathrm{O}$ analysis is a suitable and universally accepted approach for impact analyses of RE on a national level, while the approach of regional value-added modeling based on technologyspecific value chain analysis can be expected to deliver robust and reliable results for the impacts of RE for regional economic development.

However, with the exception of Germany and the UK [31], the approach of regional value-added modeling for RE has not yet been widely applied internationally. ${ }^{a}$ This paper, therefore, attempts to evaluate the possibility and methodological constraints when applying regional value-added modeling for RE to other countries. As a test case, it introduces and analyzes the results when applying the model of the Institute for Ecological Economy Research (hereafter referred to as the 'IÖW model') to Japan, thereby intending

- to assess and test the transferability of the IÖW model to other countries and to evaluate required modifications of the model

- to compare and assess the RE potential for regional value-added across countries, and to identify factors for country-specific, structural differences in regional value-added across various stages of the technology-specific value chain

To the authors' knowledge, the IÖW model or similar approaches based on regional value-added modeling have not yet been applied to Japan. Also the required data on technology-specific cost structures, revenues, and investment for the construction of technology-specific value chains have not been available for Japan but had to be compiled by the authors based on expert interviews, the analysis of individual business plans and model cases. The data, therefore, are original but have been cross-checked to the extent possible - with published data by the Japanese government and other Japanese research institutions. Efforts to match results with findings of the few available, regional I/O studies by researchers in Japan, however, have faced various methodological and practical difficulties which impede a direct comparison [32-36]. Most of the studies are rather explorative in nature, attempting to demonstrate how to integrate the RE sector into existing regional I/O tables by using a single RE technology or model plant as a reference case. To do so, they rely on national I/O tables for Japan from the year 2005, while the IÖW model for Japan is based on data from the years 2011 and 2012. The IÖW model for Japan analyzes the economic effects of RE based on an estimate for the generated regional value-added and its distribution, while the Japanese I/O-based studies focus on the direct demand effects, output and employment. This paper offers an alternative, comprehensive approach, tested extensively for Germany, to directly assess the gross economic impact of $\mathrm{RE}$ for Japan on a regional level. It provides estimates for the technology-specific regional value-added and its sources in terms of long-term business profit, employee income, and regional tax income that can be expected from the deployment of selected RE technologies in Japan. It is based on a modified IÖW model that incorporates Japan-specific features such as the national and regional tax schemes and relies on original, primary research of five representative RE technologies in Japan.

At first, the applied model of regional value-added will be introduced, describing the specific modifications from the original IÖW model to adapt to the circumstances in Japan. Then follows a comparative analysis of the underlying economics of selected RE technologies in Germany and Japan. Finally, the regional value-added of these selected technologies and its composition in Germany and Japan are compared, and possible causes for differences between Germany and Japan are investigated. The paper concludes with a discussion on methodology and practical applications of regional value-added modeling for the promotion of RE.

\section{Methods}

\section{The IÖW model}

The underlying IÖW model is composed from two main elements (Figure 1) [23].

In a first step, the model configures technology- and capacity-specific cost and revenue structures that correspond to the individual steps along the value chain of selected RE technologies and reflect the directly generated turnover of the respective technology. For this purpose, the value chains are broken down uniformly into four value-added stages: systems manufacture, planning and installation, operation and maintenance, as well as system management. Each value-added stage is further broken down into several technology-specific value-added steps. For example, in case of onshore wind power, the value chain stage of system manufacture is subdivided into individual value chain steps for the production of key components such as the tower, generator, or rotor blade. The value chain stage of planning and installation can be broken down into specific value chain steps such as system planning and design, foundation construction, or grid connection. The value chain stage of operation and maintenance covers the main value chain steps of service and maintenance, insurance, land lease, or administration, while the value chain stage of system management includes the profits and associated taxes of the system operator. Further, upstream value-adding stages and activities for example the material input for system components manufacturing are not included in this analysis. The 


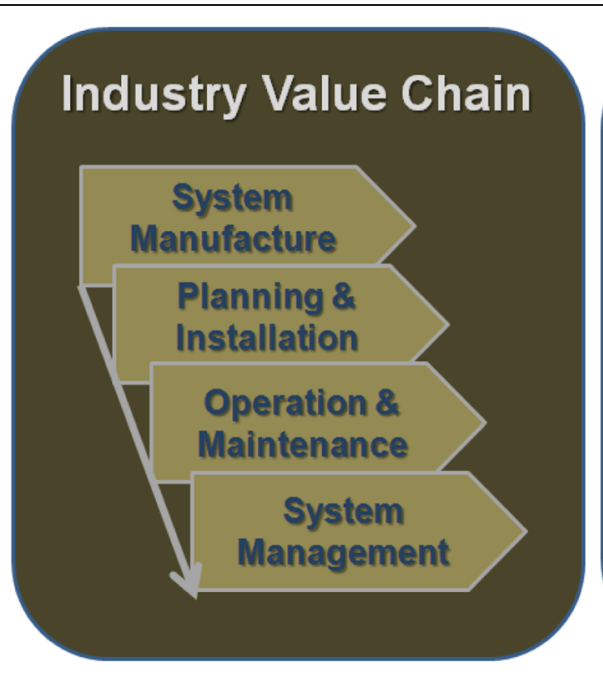

Figure 1 Elements of the IÖW model for regional value-added.

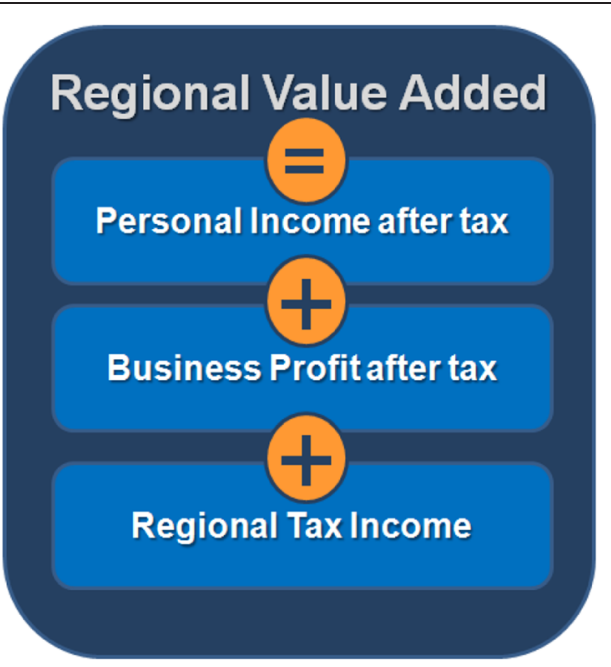

exception is the value chain for biomass which includes the provision of substrates required for system operation (e.g., wood waste).

The IÖW model assigns representative cost values to each individual value-added step of the disaggregated value chain. These reflect typical cost structures of individual $R E$ technologies and serve as the basis for the calculation of the regional value-added generated by the respective technologies at each individual value-added step. The IÖW model follows the income approach to calculate value-added, which corresponds to the net valueadded after depreciation obtained in the national accounts. The sum of net personal income, net business profit, and the regional tax revenue represents the technologyspecific net regional value-added. Each component of the net value-added is capacity-specific, calculated for each value-added step, and can be extrapolated to a given regional RE capacity or to an average plant size. The model uses specific data sets for Germany, e.g., for wages and salaries, employment quotes, or tax rates.

\section{Model building for Japan}

The model for Japan applies the identical framework and structure of the one which was developed by the IÖW and applied for Germany. The model consists of two major parts:

- Construction of value chains for specific RE technologies based on detailed, technology-specific cost and revenue structures for individual steps along the technology's value chain

- Quantification of the technology-specific regional value-added based on the estimation and addition of step-specific employee net income, net business profit, and regional tax revenue
For the purpose of testing the transferability of the IÖW model to Japan, the base year for comparison was set for the year 2012 and five representative RE technologies were selected: $150 \mathrm{~kW}$ photovoltaic roof installation, $1 \mathrm{MW}$ photovoltaic ground-mounted installation, $2 \mathrm{MW}$ onshore wind power installation, $150 \mathrm{~kW}$ smallscale hydro power installation, $5 \mathrm{MW}$ biomass installation fed by waste wood. In difference to the IÖW model, the model for Japan refrained from evaluating the regional economic effects at the stage of system manufacture, in order to simplify the comparative analysis. While the potential for value-added and employment at the stage of system manufacture is significant at the national level, RE system and components manufacturing companies have to be located within the respective region to generate value-added for a region. Because this is often not the case in many regions, it seems justified to exclude the stage of system manufacture from the comparative analysis and to focus on regional economic effects from RE at the stages of planning and installation, operation and maintenance, and system management. For each of these three stages, the model applied the same subdivided value chain steps as the IÖW model and allocated the same individual cost and revenue items for each individual step. Identical to the IÖW model, the cost and revenue data have been standardized at Japanese Yen per kilowatt.

The validity of the model rests on the availability of robust and reliable, technology-specific cost and revenue data. For Germany, the IÖW model has screened and incorporated an extensive set of detailed, technologyspecific data that have been derived from a broad range of current literature such as evaluation reports, studies, or government statistics and have been updated over time. The analysis for Germany draws on the results of the 
IÖW model for 2012 (Hirschl B, Heinbach K, Prahl A, Salecki S, Schröder A, Aretz A, Weiß : Wertschöpfung durch Erneuerbare Energien - Ermittlung der Effekte auf Länder- und Bundesebene, forthcoming). For the analysis of technology cost developments, additional data from 2009 have been used [25]. The data for Germany were computed into Japanese Yen at the exchange rate of 130 yen per euro which - incidentally - was roughly the average exchange rate in years 2009 and 2012, thereby simplifying the comparative analysis.

For Japan, a similar comprehensive and robust set of data is yet not available due to the comparatively sparse amount of current literature and published government data. The reports of the Feed-In-Tariff Evaluation Committee (Chōtatsu Kakakutō Santeiiinkai) of the Ministry of Economics, Trade and Industry (METI), which decides on the feed-in tariffs for individual RE technologies (first applied from July 2012), are supposedly the most comprehensive and reliable data source. However, compared to Germany, the official data for Japan on investment and operating costs proved to be rather fragmented, limited in scope and level of detail [37-39]. Further, comparison with data provided by various business associations in the RE industry and by Japanese research institutions reveal a high degree of variation of the provided data themselves as well as in regard to the cited reference base of installations, which mixes figures on actual operations, model plants, and estimates for ongoing projects [40-46]. Yet, no further details are provided on the breakdown of total system costs and possible reasons for the substantial deviations. The level of breakdown of technology-specific operating costs into individual cost items is also insufficient for the purpose of constructing technology-specific value chains for Japan.

Therefore, the Japan model draws on data from business plans and reports for a comparatively small number of reference cases for the selected RE technologies, derived from RE projects in the period of $2011 \sim 2012$. In the case of solar power, two references cases for $150 \mathrm{~kW}$ roof installation and $1,000 \mathrm{~kW}$ ground-mounted installation were selected which were launched in 2011 as regional model cases with the support of the Japanese Ministry of Environment. Panels were supplied by Japanese manufacturers and planning and construction handled by regional firms. While for electrical installation and land rent, standard costs were assumed, and operational cost data were provided by the operator for 2012. In case of wind power, the Japan Wind Power Association provided data from a typical business plan for a wind farm with ten or more $2 \mathrm{MW}$ installations. The system costs and operational cost structures for a $200 \mathrm{~kW}$ hydro power plant refer to a typical reference case provided by the National Small Hydro Power Promotion Association (zenkoku shōsuiryokuriyō suishinkyougikai) taking into account representative conditions for construction, water flow volume, and difference in altitude. For biomass, an installation of a $5 \mathrm{MW}$ biomass facility based on waste wood in Fukushima Prefecture was taken as a reference applying the available business plan for the investment, operational, and substrate costs. Though limited in scope, these data proved to be consistent with the data ranges for average investment and operational costs provided by the Japanese government, related business associations, and Japanese research institutions. Nevertheless, the described variance and limited scope of the available data set for Japan generally inhibits the robustness of results.

The calculation of the regional, technology-specific value-added requires the estimation of net personal income, net business profit, and regional tax revenue on the individual steps of the respective value chains. Based on the rationale that individual steps of the value chain correspond with typical industry sectors, the IÖW model draws on industry-specific, average cost and profit ratios that are publically available for Germany from government institutions such as Germany's central bank, called Deutsche Bundesbank, and the German Federal Statistical Office. The application of industry-specific averages is justified by the notion that the companies involved along the various stages and steps of the RE value chains can be categorized within the existing classification of economic activities with corresponding cost and profit structures. In other words, the IÖW model assumes that companies would not engage in the RE business unless they can expect at least similar returns typical for the industries they associate with. For the short term, this assumption may underestimate the actual level of profitability of companies engaged in various stages along the RE-related value chains due to temporary supply-demand conditions or the use of subsidies or other incentives. Yet, it can also be expected that over the long term, these distortions level off and profits converge to a level typical for the respective industry. Furthermore, for the calculation of pre-tax profits at the stage of system management, the IÖW model applies the actual average return on equity for the individual RE technologies which were drawn from the Renewable Energy Sources Act (EEG) Progress Report [23].

Following the same logic, the model for Japan calculates the regional value-added based on industry-specific statistics by the Japanese government, namely the Financial Statements Statistics of Corporations by Industry (Hōjin Kigyō Tókei) compiled by the Policy Research Institute of the Japanese Ministry of Finance [47]. The data are extrapolated from the results of the annual survey among approximately 28,000 representative non-financial and financial firms (with capital, contributions, or funds of 10 million yen or more) about their provisional profit-andloss-accounts and balance-sheets. The surveyed companies are categorized into different classes of capital size and 
classified into different industries in accordance with the Japan Standard Industrial Classification which correspond in principle with the German classification. The results cover the account settlements of more than 2.8 million Japanese firms across all industries. Data include industryspecific sales revenues, gross margin, profits before and after tax, as well as personnel expenses (including salaries and bonuses) for full-time employees and management, depreciation, and interest payments.

For the purpose of this study, the key individual steps of the technology-specific value chain have been associated with the following industries, applying the respective ratios for business profit and personnel expenses, in order to derive the values for personal gross income and business profit before tax. For these industries average figures over the 3-year period from $2010 \sim 2012$ were applied, in order to avoid one-time distorting effects (e.g., impact from Lehman shock)

- Planning and installation:

- Planning/project management: academic, professional and technical services (Code 83)

- Site preparation/construction/electric installation: construction (Code 15)

- Operation and maintenance:

- Service and maintenance: other technical services (Code 89)

- Insurance: insurance (Code 96)

- Banking: banking (Code 91)

With the exception of banking and insurance, large-size firms with capital of 1 billion yen or more were excluded from the database, in order to better reflect the structural characteristics of firms involved at the various stages of the RE business. This assumes that the planning, project management, construction/installation, as well as servicing and maintenance of RE projects are predominantly handled by smaller and medium-sized firms. This assumption is confirmed by analyzing the company profiles of 334 private companies in the field of RE that are registered in the Database of Renewable Energy Research Organizations \& Companies in East Asia from the New Energy Foundation (NEF) [48]. The database includes a significant number of large, integrated manufacturing firms such as Mitsubishi Heavy Industries, Hitachi, or Kyocera who are major competitors in RE-related equipment. As these companies focus on manufacturing, which is excluded from this analysis, it can be safely assumed that the various RE-related service activities at the stage of planning, construction, operation, and system management are handled, if at all, by the companies' sales, service, or engineering divisions, or independent subsidiaries. The cost structures of these overhead divisions or subsidiaries are likely to resemble those of specialized service companies rather than those of integrated, manufacturing-oriented conglomerates. The same is true also in case of large, general construction firms like Taisei Corporation or Shimizu Corporation who are also active in the field of RE. The majority of nonmanufacturing companies in the field of RE are specialized, medium-sized firms that provide services such as engineering/procurement/construction (EPC), project consulting, system integration, trading, service and maintenance, or the supply of substrates and input materials in the case of biomass and bio fuels. Even the largest EPC providers, system integrators, and operators like Softbank Energy (92 employees/746 million Yen equity), Eurus Energy (253 employees/1.8 billion Yen equity), Japan Wind Development (148 employees/1 billion equity), IHI Plant Construction (471 employees/471 million Yen equity), or NTT Facilities (5,000 employees/1.2 billion Yen equity) still fall more in the category of typical medium-sized companies. A certain exception are the operating firms of bio-fuel and biomass plants which often have been installed at the manufacturing sites of larger companies in the food, paper, and pulp industry to utilize their biomass waste. The NEF database has also been cross-checked with the member directories of the main Japanese business associations in the field of RE, such as the Japan Photovoltaic Energy Association (162 members), The Japan Wind Power Association (127 members), the Committee for the Promotion of the Use of Woody Biomass Energy (112 members), and the National Small-Scale Hydro Promotion Committee (99 members). Many of the member firms are also registered in the NEF database, and companies not registered are frequently smaller and medium-sized firms.

For the stage of system management, the IÖW model can draw on the official profitability data published in the Renewable Energy Sources Act Progress Report ('EEG-Erfahrungsbericht') of the German government. No such data are yet made publically available by the Japanese government. Therefore, the model for Japan relies on the cash flow projection and internal-rate-ofreturns (IRR) of selected RE reference projects. Revenues have been calculated based on the technology-specific feed-in tariffs for the year 2012.

\section{Taxes}

The tax system marks substantial differences between Germany and Japan, therefore requiring various adaptations of the tax model to reflect the characteristics of Japan's tax system. In regard to income-based taxes, the IÖW model takes into account whether a business is incorporated or self-employed as the tax base and rates differ. The statistical base for this distinction is provided by the enterprise statistics of the Deutsche Bundesbank. For Japan, the MoF statistics only refer to incorporated business; however, no major distorting effect is expected for the purpose of this study, as most businesses in Japan are 
incorporated as stock companies, limited liability partnerships, cooperatives, or public business associations ( $k o j j e k i$ hōjin such as shadan hōjin) who are subject to corporate income tax. It is assumed that businesses who deal with the considered RE technologies usually are likewise choosing an incorporated form of business association. An overview on the applied tax model is given in Table 1 which summarizes the main national and regional tax categories and the applied rates and formulas.

In order to calculate the net personal income and net business profit, the model for Japan takes into account the Japanese national and regional income-related, personal, and corporate taxes. The calculation of the national personal income tax (shotokuzei) assumes the average taxable personal income of 4.08 million Japanese Yen (in 2011), on which a $20 \%$ national income tax is levied [51]. For the calculation of the national corporate tax (höjinzei), it is assumed - for the reasons stated above - that the majority of firms involved in the RE business are small- to mediumsized firms with capital less than 100 million Japanese Yen, applying a reduced national corporate tax rate of $18 \%$ valid in 2012. The threshold of 100 million Japanese Yen may be too restrictive, as also higher-capitalized firms engage in RE-related activities. However, the risk of overstating tax income is deemed to be significantly higher considering the fact that the break-even for system operators takes often several years and that tax breaks are rather common in the RE industry.

To these national income-related taxes, regional income taxes are added to derive the net personal income and net business profit. For Germany, the IÖW only refers to the municipal tax revenue as part of regional value-added. For Japan, however, regional value-added refers to both, municipal as well prefectural tax revenue as regional tax revenue. This distinction is important, as most of the 47 prefectures in Japan are far smaller in terms of population and geographic size than most German federal states (Bundesländer). Therefore, the regional economic impact of RE is deemed to be equally important on both, the municipal as well as the prefectural level. The distinction between effects on prefectural and municipal level is expected to provide further valuable insight for the evaluation of regional economic effects of RE in Japan.

The predominant source of municipality tax revenue in Germany is based on corporate and personal income, specifically the local trade tax (Gewerbesteuer) on business profits and the share of the national tax on salaries and wages. In Japan, there are three main bases for regional (municipal and prefectural) tax revenue: corporate and personal income, fixed assets, consumption [50].

Differing from the IÖW model, the regional tax model for Japan only considers those taxes that are directly levied by the regions but excludes the regional share of redistributed national taxes (chihō kófuzei), because the criteria and bases for redistribution depend largely on the state of local public finances and allow for significant discretionary judgment by the Japanese national government.

Japanese regions levy two forms of corporate income taxes, the corporate residential tax (höjin juminzei) and

Table 1 Overview on the Japanese tax system

\begin{tabular}{|c|c|c|c|c|}
\hline \multirow[t]{2}{*}{ National taxes } & & \multicolumn{3}{|l|}{ Regional taxes } \\
\hline & & & Prefecture & Municipality \\
\hline Personal income tax (percent of taxable income) & $20 \%$ & Personal income tax & & \\
\hline \multirow[t]{12}{*}{ Corporate tax (percent of taxable income) } & $18 \%$ & Residential tax (minimum rate in JPY)* & 1,000 & 3,000 \\
\hline & & Residential tax (percent of taxable income) & $4 \%$ & $6 \%$ \\
\hline & & Corporate income tax & & \\
\hline & & $\begin{array}{l}\text { Local business tax (percent of taxable income/not } \\
\text { applied to system operator) }\end{array}$ & & $4 \%$ \\
\hline & & Electric utility tax (percent of revenue of system operator) & $0.7 \%$ & \\
\hline & & $\begin{array}{l}\text { Special regional corporate tax for electric utilities } \\
\text { (percent of electric utility tax) }\end{array}$ & $81 \%$ & \\
\hline & & Residential tax (minimum rate in JPY) ${ }^{* *}$ & $20,000 \sim 50,000$ & $50,000 \sim 150,000$ \\
\hline & & Residential tax (percent of taxable income) & $5 \%$ & $12.3 \%$ \\
\hline & & Asset-based tax & & \\
\hline & & $\begin{array}{l}\text { Operator fixed asset tax (percent of depreciated, } \\
\text { registered asset value) }\end{array}$ & & $1.4 \%$ \\
\hline & & Consumption-based tax & & \\
\hline & & Operator consumption tax (percent of value-added) & $0.5 \%$ & $0.5 \%$ \\
\hline
\end{tabular}

*Calculated as ratio of income from minimum residential tax to overall tax income from residential tax (2.37\% in 2012).

** Calculated as ratio of income from minimum residential tax to overall tax income from residential tax (in 2012: prefecture $=22.9 \% /$ municipalities $=25.8 \%$ ).

Source: MIAC (2014) [49], KPMG (2012) [50]. 
the corporate business tax (höjin jigyōzei). The overall tax rate for the corporate residential tax amounts to $17.3 \%$ of the taxable income, $5 \%$ on prefectural level and $12.3 \%$ on municipal level. In addition, a fixed corporate residential tax is charged to every business, the amount of which varies, however, depending on the size of equity and the number of employees of the firm. There are a total of 14 different tax classes, making it rather impractical for modeling. For the purpose of this analysis, the amount of the fixed corporate residential tax has been estimated by applying a mark-up on the income-related corporate residential tax. The mark-up has been calculated as the ratio of the regional tax income from the fixed corporate residential tax to the regional tax income from the income-related corporate residential tax.

In Japan the system operators of RE are in general not subject to the corporate business tax (höjin jigyōzei) but are charged a special form of the corporate business tax called electricity utility business tax (denkijigyozzei). A tax rate of $1.3 \%$ is levied by the prefecture on the revenue from electricity sales by RE system operators. The tax rate is presently reduced to $0.7 \%$. On top of this tax, a special regional corporate tax is charged that amounts to $81 \%$ of the special electricity utility business tax. However, companies who have also invested into RE next to their main business, but where revenues from electricity sales amount to less than $10 \%$ of their main business, are exempt from this tax and are even allowed to offset profits from their RE operation against losses in their main business. This exemption serves as an incentive for local businesses by regional government to invest into RE.

The corporate business tax is levied only on prefectural level, and tax rates vary according to the size of the company. For the reasons stated above, it is assumed that the majority of businesses in Japan that are involved in the RE-related business are small- to medium-sized firms, cooperatives, or public business associations with less than 100 million yen equity capital and less than 8 million yen in taxable income on average. The model assumes an average, uniform tax rate of $4 \%$ on profits of these businesses.

Prefectures and municipalities also levy a uniform personal residential tax (kojin juminzei) of $10 \%$ on personal income, salaries, and wages of individual citizen. In addition, there is a per capita personal residential tax of 1,500 yen on prefectural level and $6 \%$ or a minimum of 3,000 yen on municipal level. For the purpose including this rather insignificant tax into the model, a mark-up on the personal residential tax was applied, similar to the approach taken for the fixed corporate residential tax.

One of the main sources of tax revenue for municipalities in Japan is the fixed asset tax which contributed $42.7 \%$ of all municipal tax revenue in 2012. A uniform tax rate of $1.4 \%$ is annually levied on the registered, depreciated value of properties, real estate and other fixed assets, and investments into RE are also subject to the fixed asset tax. The modeling and estimate of the fixed asset tax for RE, however, poses substantial methodological difficulties, as the depreciation curve of the $\mathrm{RE}$ investment has to be taken into account. Furthermore, many prefectures and municipalities provide exemptions or reductions of the fixed asset tax as part of their promotional policies of RE. For the purpose of the comparative analysis, an average tax burden per kilowatt has been estimated based on the technology-specific cash flow plans and a depreciation period of 20 years. It has to be noted that region-specific circumstances have to be taken into consideration, when applying the model to a specific region.

A further source of regional tax revenue is their share of the Japanese consumption tax (shōhizei), consumption being defined as the purchase value minus the value of external purchases of input materials. In other words, it is a value-added tax. Purchases of RE equipment and related services, as well as the revenue generated from RE system operation are subject to a uniform $5 \%$ consumption tax, $1 \%$ of which is redistributed to regions $(0.5 \%$ each on prefectural and municipality level). In 2012, the consumption tax already accounted for $17.1 \%$ of the regional tax revenue, and its significance is expected to grow further, as the Japanese government has raised the consumption tax to $8 \%$ from 1 April 2014 with further increase expected in the near future. For the comparative study, a uniform tax rate of $5 \%$ was applied only to the revenues on system operating stage, as the analysis does not take into account the regional economic effects of system manufacture.

Other kind of taxes that are charged on a regional level have been excluded as they are either not relevant for RE businesses or only applied in certain regions like Tokyo.

In order to calculate the amount and share of regional tax revenue for each RE technology, the income-based tax rates were applied to the gross personal income and gross business profit per kilowatt, thereby obtaining the net personal income and net business profit. The fixed asset tax and the special electricity utility tax are treated as cost items that reduce the system operator's pre-tax business profit. The consumption tax is levied on the system operator's revenue, deducting the costs for external material input, bank interest payments, and insurance premiums.

Just like the IÖW model, the sum of net personal income, net business profit, and the regional tax revenue leads to the technology-specific net regional value-added. The model results only reflect the regional value-added directly generated by RE technologies along the planning and installation, operation and maintenance, and system management stages of the 
technology-specific value chain. Further, indirect effects that are generated through these economic activities further upstream the RE value chains (e.g., production of raw materials) as well as induced effects such as multiplier income effects by the induced consumption or investment are not considered. Negative economic effects such as the replacement of economic activity in the field of conventional energy technologies and the subsequent loss of employment and business profit are also not considered.

The model results distinguish between one-time effects of regional value-added at the stage of planning and installation, and ongoing, annual value-added generation along the lifespan of RE at the stage of operation and maintenance as well as the stage of the RE system management. The model results reflect the overall potential for technology-specific regional value-added for all of Japan and Germany, assuming that all the value generating activities are located and performed within the two countries. The results are considered to be valid and robust, as the stage of system manufacture is excluded from the comparative analysis, thereby avoiding the cumbersome task of integrating differences in the structure of international trade in the field of RE technologies into the model.

\section{Results}

The comparative analysis between Germany and Japan is conducted in two steps. As a first step, the underlying economics of the five selected RE technologies are compared, applying return-on-equity (ROE) as well as the return-onsales (ROS) as the key indicators for economic performance. The ROE indicates the overall investment performance of the respective RE technologies, while the ROS highlights the operational economic performance specifically at the system operating and management stage. The analysis allows to assess possible country-specific differences in the economic performance of RE businesses and to identify possible root causes for such differences at the stage of investment and system operation. Due to the substantial differences in the tax systems of Germany and Japan and the possible distorting influences of different tax bases and rates, the analysis is based on pre-tax business profit. Furthermore, as the legal depreciation period differs between Japan (17 years) and Germany (20 years), the data have been standardized for a depreciation period of 20 years to make them comparable.

In a second step, the technology-specific regional valueadded per kilowatt for Germany and Japan are compared for each RE technology. Rather than merely comparing the absolute amount of net regional value-added by RE technology, the analysis concentrates on differences in the composition of the regional value-added, thereby highlighting differences in the sources of regional value-added and their relative weight. In addition, the comparative analysis distinguishes between the one-time value generation at the stage of investment or installation, and ongoing annual effects over the lifespan of the RE technology. The comparative analysis of RE technologies reveals significant differences between Germany and Japan in terms of total investment costs, economic performance, and the resulting composition of regional value-added.

\section{Investment costs}

As shown in Table 2, for the year 2012, the total investment costs - including direct investment for the equipment as well as the associated costs related to the planning and installation of the RE facilities - run 1.6 to 2 times higher in Japan than in Germany for all RE technologies under consideration; the only exception is biomass where total investment costs are similar in both countries. Further analysis of the 2012 data reveals that for solar and wind installations, the direct investment costs in Japan are $1.7 \sim 1.8$ times higher than in Germany, while the direct investment costs for smallscale hydro power and biomass are lower in Japan. Especially in regard to wind power, the FIT system has not yet generated growth of wind power in Japan, and direct investment costs have remained at significant higher levels compared to Germany and other markets. Recent data for 2013 from the Feed-in-Tariff Evaluation Committee (Chōtatsukakakutō Santeiiinkai) of the Japanese METI, which reviews and decides on the annual feed-in tariffs for RE in Japan, also underline the significant higher investment costs in Japan, although equipment costs have dropped recently also in Japan, in particular for solar installations [52]. In case of solar power, one reason may be the dominance of Japanese suppliers, who command about $80 \%$ of the domestic solar panel market and tend to charge higher prices to Japanese consumers. Another reason may be the significant recent devaluation of the Japanese Yen, which has led foreign suppliers of equipment and components to raise prices on the Japanese market. This implies that the worldwide dynamic reduction of equipment costs for RE technologies have not yet fully found its way to the Japanese market. In general, investment costs in Japan in the year 2012 are at a similar level as those in Germany in the year 2009.

In addition, other investment costs related to planning, projecting, construction, and installation are also markedly higher in Japan as compared to Germany. While other investment costs for medium-scale solar roof installations record a comparatively modest mark-up of 30\% in Japan, they are $2 \sim 3$ times higher for wind, small-scale water power and biomass installations. The share of other investment costs as percentage of the total investment in Japan is between 10-percentage points (1 MW solar, 
Table 2 Comparison of cost structures and performance of renewable energy by type of technology for Germany and Japan

\begin{tabular}{|c|c|c|c|c|c|c|c|c|c|c|c|c|c|c|c|}
\hline \multirow{3}{*}{$\begin{array}{l}\text { Cost and revenue structures (JPY/kW) } \\
\text { (for installations in the year 2012) }\end{array}$} & \multicolumn{6}{|l|}{ Solar } & \multirow{2}{*}{\multicolumn{3}{|c|}{$\begin{array}{l}\text { Wind } \\
\text { 2,000 kW (onshore) }\end{array}$}} & \multirow{2}{*}{\multicolumn{3}{|c|}{$\frac{\text { Hydro }}{200 \mathrm{~kW}}$}} & \multirow{2}{*}{\multicolumn{3}{|c|}{$\begin{array}{l}\text { Biomass } \\
5,000 \mathrm{~kW} \text { (wood) }\end{array}$}} \\
\hline & \multicolumn{3}{|c|}{150 kW (roof) } & \multicolumn{3}{|c|}{$1,000 \mathrm{~kW}$ (ground) } & & & & & & & & & \\
\hline & Germany & Japan & $J P / G E R$ & Germany & Japan & $J P / G E R$ & Germany & Japan & $J P / G E R$ & Germany & Japan & $J P / G E R$ & Germany & Japan & $J P / G E R$ \\
\hline \multicolumn{16}{|l|}{ At planning and installation stage } \\
\hline Total investment & 235,300 & 369,533 & $157 \%$ & 208,000 & 372,000 & $179 \%$ & 177,190 & 360,673 & $204 \%$ & 968,108 & $1,587,500$ & $164 \%$ & 502,154 & 478,400 & $95 \%$ \\
\hline Direct investment cost & 149,240 & 260,000 & $174 \%$ & 140,504 & 238,000 & $169 \%$ & 130,000 & 230,000 & $177 \%$ & 683,668 & 600,000 & $88 \%$ & 432,464 & 287,000 & $66 \%$ \\
\hline $\begin{array}{l}\text { Indirect investment cost } \\
\text { (e.g. planning/construction) }\end{array}$ & 86,060 & 109,533 & $127 \%$ & 67,496 & 134,000 & $199 \%$ & 47,190 & 130,673 & $277 \%$ & 284,440 & 987,500 & $347 \%$ & 69,690 & 191,400 & $275 \%$ \\
\hline \multicolumn{16}{|l|}{ At system operation stage } \\
\hline Operating cost & 20,246 & 34,005 & $168 \%$ & 18,184 & 31,158 & $171 \%$ & 19,444 & 33,269 & $171 \%$ & 68,048 & 139,112 & $204 \%$ & 114,984 & 184,957 & $161 \%$ \\
\hline Operator revenue & 26,430 & 42,048 & $159 \%$ & 26,998 & 37,843 & $140 \%$ & 25,966 & 38,544 & $148 \%$ & 90,055 & 177,828 & $197 \%$ & 136,577 & 201,830 & $148 \%$ \\
\hline Profit before tax & 6,184 & 8,043 & $130 \%$ & 8,814 & 6,685 & $76 \%$ & 6,522 & 5,275 & $81 \%$ & 22,006 & 38,716 & $176 \%$ & 21,593 & 16,873 & $78 \%$ \\
\hline ROS from operation (before tax)* & $23.4 \%$ & $19.1 \%$ & $-4.3 \%$ & $32.6 \%$ & $17.7 \%$ & $-15.0 \%$ & $25.1 \%$ & $13.7 \%$ & $-11.4 \%$ & $24.4 \%$ & $21.8 \%$ & $-2.7 \%$ & $15.8 \%$ & $8.4 \%$ & $-7.4 \%$ \\
\hline ROE from operation (before tax) ${ }^{* *}$ & $8.5 \%$ & $7.3 \%$ & $-1.2 \%$ & $7.4 \%$ & $6.0 \%$ & $-1.4 \%$ & $13.9 \%$ & $4.9 \%$ & $-9.0 \%$ & $7.0 \%$ & $8.1 \%$ & $1.1 \%$ & $11.6 \%$ & $11.8 \%$ & $0.2 \%$ \\
\hline \multicolumn{16}{|l|}{ Investment-related ratios } \\
\hline Operating cost/total investment & $9 \%$ & $9 \%$ & $1 \%$ & $9 \%$ & $8 \%$ & $0 \%$ & $11 \%$ & $9 \%$ & $-2 \%$ & $7.0 \%$ & $9 \%$ & $2 \%$ & $23 \%$ & $39 \%$ & $16 \%$ \\
\hline Other investment/total investment & $37 \%$ & $30 \%$ & $-7 \%$ & $32 \%$ & $36 \%$ & $4 \%$ & $27 \%$ & $36 \%$ & $10 \%$ & $29 \%$ & $62 \%$ & $33 \%$ & $14 \%$ & $40 \%$ & $26 \%$ \\
\hline
\end{tabular}

*Own calculation based on primary research data on cost, investment, and equity for Japan and on IÖW data for Germany (Hirschl B, Heinbach K, Prahl A, Salecki S, Schröder A, Aretz A, Weiß : Wertschöpfung durch Erneuerbare Energien - Ermittlung der Effekte auf Länder- und Bundesebene, forthcoming); ROE figures for Germany are referring to the underlying assumptions of the German government and public research institutions on ROE industry averages for RE projects which are applied for the determination of technology-specific feed-in-tariffs; these assumptions are published in the review report on the Renewable Energy Law ('EEG Erfahrungsbericht').

**The underlying equity ratios differ slightly between Japan and Germany: for Japan 30\%; for Germany: 25\% (water/wind), 30\% (150 kW solar/biomass), 50\% (solar 1 MW)/exchange rate: 130JPY/Euro. 
2 MW wind) and up to more than 30-percentage points (small-scale hydro, biomass) higher than in Germany. Significant differences in these so-called 'balance-of-system' costs are rather common worldwide, as international comparative studies have revealed; yet, the order of magnitude for Japan is remarkable [53,54]. A general reason is assumed to be higher construction and electrical installation costs, as well as overall project management costs. Higher construction and electrical installation costs may be caused by stricter construction standards to cope with the risks of earthquakes, typhoons or lightning, and landrelated regulations, while lengthy approval processes and administrative standards (e.g., environmental assessment) may cause higher planning and project management costs. Furthermore, the reconstruction of the Northern Japan after the devastating earthquake and tsunami in March 2011 has led to a shortage of construction workers and a rise in construction wages. The recent review of METI provides further evidence by listing various administrative regulations related to grid access and connection, to the use of water or agricultural land rights (e.g., solar and water power installations), to forest administration (e.g., wind power, water power, biomass), and to building standards (e.g., wind power) as examples that lead to timeconsuming planning and approval procedures which then drive up costs [55]. A recent report by the EU-Japan Centre for Industrial Cooperation also cites various regulations and administrative procedures that inhibit competition and tend to drive up costs [56].

\section{Economic performance}

Higher total investment costs are surely one reason for the Japanese government's decision to grant rather generous feed-in tariffs as compared to Germany. For 2012, the Japanese feed-in tariffs for RE technologies under consideration have been generally about twice as high as those that have been applied in Germany in the same year. It, therefore, could be assumed that RE installations in Japan would generate returns at least similar or even higher than similar installations in Germany. As summarized in Table 2, the comparative analysis of the performance in terms of ROS and ROE, both before tax, leads to different conclusions: medium-scale solar roof installations as well as small-scale hydro power installations achieved comparable returns in Germany and Japan in 2012 both in terms of ROS and ROE. But in case of larger-scale groundmounted solar plant, wind power plant, and large-scale biomass facility projects in Germany delivered significantly higher operating returns. The differences in economic performance is particularly marked in the case of wind power (2 MW), where German installations on average generated a solid ROS of $25 \%$ and an ROE of almost $14 \%$, as compared to a ROS of a $13.7 \%$ and a ROE of just $4.9 \%$ for Japan. Similarly, ground-mounted solar installations
(1 MW) in Germany recorded an impressive ROS of $33.7 \%$ and a ROE of $8.5 \%$ as compared to an ROS of $13.4 \%$ and an ROE of $6 \%$ in Japan. ${ }^{\text {b }}$ In case of a largerscale biomass plant ( $5 \mathrm{~W}$ ) fed on waste wood, the level of ROE is comparable, but the ROS in Japan of $8.4 \%$ is almost half of that for a similar installation in Germany in 2012 (15.8\%).

A more detailed analysis of the underlying cost structures leads to interesting conclusions in regard to possible reasons for the significant divergence in the economic performance of RE facilities in both countries.

The ROS, on the one hand, depends on the revenue generated by the RE installation, and, on the other hand, on the level of operating costs to run the facility. As indicated above, rather generous feed-in tariffs in Japan lead to revenue per kilowatt that is between 1.4 times (solar ground-mounted installation) to 2.1 times higher (smallscale hydro power) than in Germany. Therefore, the comparatively weaker operational performance of RE installations in Japan is largely caused by operating costs in Japan that run higher by a factor of 1.5 to 2.0 than those in Germany. The imbalance of revenue to operating costs is most marked in the case of large-scale ground-mounted solar and wind power and to a lesser degree in case of biomass, which is reflected in the significantly lower ROS of these technologies as compared to Germany.

A main reason for these differences is the substantially higher depreciation burden due to the higher total investment costs in Japan. However, direct personnel costs as well as costs for service and maintenance run higher in Japan by a factor of 1.4 (solar) up to 3.8 (wind power). Further analysis into the root causes for higher share of direct personnel and service costs is required, but it may be assumed that administrative regulations which, for instance, require the employment of qualified engineering staff are pushing up operating costs. Furthermore, higher and further rising real estate prices are driving up the costs for land leases in the case of ground-mounted solar and wind power installations. In the case of biomass, the substrate costs exceed those in Germany by a factor of 3.3 .

The differences in regard to ROE can only partially be explained by differences in the underlying equity ratio: for Japan, a unified equity ratio of $30 \%$ was applied, while for Germany the equity ratio varied between $25 \%$ (small-scale hydro power, wind), 30\% (solar roof installation), and 50\% (solar ground-mounted installation). The slightly lower equity ratio for small-scale hydro power and wind power does not sufficiently explain the significant divergence in ROE, and in case of large-scale ground-mounted solar installations, the ROE in Germany would even increase further when applying the lower equity ratio of Japan. The substantially lower ROE in Japan for mainstream RE technologies such as large- 
scale ground-mounted solar, wind power, and largerscale biomass installations is mainly caused by the higher total investment costs, which reduce the asset turnover rate, and further depressed by the substantially higher operating costs which reduce the ROS.

\section{Regional value-added}

Total investment costs for RE at the stage of planning and installation, as well as the revenue from the sales of $\mathrm{RE}$ at the stage of system operation define the overall pool of value that a region can theoretically capture from the investment and operation of RE. As total investment costs for RE as well as the revenue for RE from feed-in tariffs differ significantly between Germany and Japan, a comparison of the absolute values for the generated regional value-added has only limited meaning. It, therefore, makes more sense to compare the relative shares of regional value-added of indirect investment costs at the stage of planning and investment, as well as of the annual sales revenue during operation. These ratios indicate to what extent the regional economy benefits from RE in the shape of personal income, business profits, and regional taxes.

As shown in Table 3, a significantly higher share of the indirect investment costs for planning and installation remain as regional value-added in Germany $(22 \% \sim 44 \%)$ than in Japan $(13 \% \sim 16 \%)$. The results show that personal income accounts for the predominant share of regional value-added in both countries at investment stage, while the share of business profit and regional tax income is comparatively smaller in both countries. However, in Japan employees receive a relatively larger portion from the available value pool than in Germany, while in Germany business profits appropriate a substantially higher share of regional value-added than in Japan.

While the share of regional value-added at planning and investment stage differs sharply between Germany and Japan, the share from annual revenues that remains as value-added in the region during system operation is rather comparable across all RE technologies $(21 \% \sim 33 \%)$.

However, in respect to the composition of the regional value-added, there exist remarkable differences between Germany and Japan. In Germany, after-tax business profits account for $60 \%$ (hydro power, biomass) to more than $70 \%$ (solar, wind) of the regional value-added. In Japan, after-tax profits also contribute the highest share of regional valueadded, but it ranges only between $28 \%$ (biomass) and $47 \%$ $\sim 50 \%$ (solar, wind, hydro power). In Japan, a far higher share between 20\% 25\% generally goes to municipal (and also prefectural) taxes (with the exception of biomass), while in Germany municipal taxes account for only between $11 \% \sim 15 \%$. Similarly, the share of regional value that is distributed as personal income after tax is also about 1.5 to 2 times higher in Japan ( $28 \% \sim 32 \% / 62 \%$ for biomass) as compared to Germany (12\% 23\%/37\% for biomass). These differences in the structural composition of the regional value-added in Germany and Japan can be explained, on the one hand, by the significant higher operating performance of RE facilities in Germany and, on the other hand, by distinct differences between the regional tax systems of both countries. Specifically, the fixed-asset tax that is levied on RE assets in Japan is a major source of municipal tax income accounting for about $50 \%$ of the municipal tax income from RE installations. In addition, Japanese regional tax authorities also benefit from the special electricity utility tax and receive comparatively higher share of the taxable personal income and business profit as their German counterparts.

\section{Discussion}

The overriding purpose of the comparative analysis of the regional value-added generated by RE in Germany and Japan has been to assess and test the transferability of the IÖW model to other countries.

The analysis has demonstrated that the IÖW model and its underlying combination of technology-specific value chain analysis with national industry statistics can be meaningfully applied to different countries and produces robust and reliable results for measuring and assessing the regional economic impact of RE technologies. However, it has also become evident that the transfer of the IÖW model depends on the availability of sufficient data and requires various modifications in order to reflect country-specific characteristics.

First, the reliability of the modeling results for regional value-added depends on the availability of a robust and broad set of data on technology-specific cost and revenue structures of RE along the various steps of the specific value chain. Compared to Germany, the available data in Japan are still rather limited in terms of scope, quality, level of detail, and historical development. The comparative analysis for Japan had to rely on a few reference cases in order to obtain the required details on cost structures and revenues. Although they generally proved to be compatible and consistent with other publicly available data from the Japanese government and think tanks, the published data sets are rather fragmented and reveal a significant variance, in particular in regard to total system costs. Such significant deviations in the total system costs have a fundamental impact on the economical viability of RE and impede the generalization of representative data. However, with the growing installation base of RE in Japan, a broader set of data should become available, in particular for solar power installations, thereby enhancing the reliability and robustness of the applied model for Japan.

Secondly, the estimation of the regional value-added relies on the availability of national, industry-specific statistics in order to estimate the profitability and labor 
Table 3 Comparison of regional value-added (RVA) of renewable energy by type of technology for Germany and Japan

\begin{tabular}{|c|c|c|c|c|c|c|c|c|c|c|c|c|c|c|c|}
\hline \multirow[t]{3}{*}{ Regional value-added (RVA)* } & \multicolumn{6}{|l|}{ Solar } & \multirow{2}{*}{\multicolumn{3}{|c|}{$\frac{\text { Wind }}{2,000 \mathrm{~kW} \text { (onshore) }}$}} & \multirow{2}{*}{\multicolumn{3}{|c|}{$\begin{array}{l}\text { Hydro } \\
200 \mathrm{~kW}\end{array}$}} & \multirow{2}{*}{\multicolumn{3}{|c|}{$\begin{array}{l}\text { Biomass } \\
5,000 \mathrm{~kW} \text { (wood) }\end{array}$}} \\
\hline & \multicolumn{3}{|c|}{$150 \mathrm{~kW}$ (roof) } & \multicolumn{3}{|c|}{$1,000 \mathrm{~kW}$ (ground) } & & & & & & & & & \\
\hline & Germany & Japan & $J P / G E R$ & Germany & Japan & $J P / G E R$ & Germany & Japan & $J P / G E R$ & Germany & Japan & $J P / G E R$ & Germany & Japan & $J P / G E R$ \\
\hline At planning/construction stage (JPY/kW) & 27,066 & 14,307 & & 20,595 & 18,013 & & 11,194 & 18,089 & & 124,981 & 136,639 & & 18,532 & 33,693 & \\
\hline RVA as percent of indirect investment cost & $22.0 \%$ & $13.1 \%$ & $-8.9 \%$ & $22.4 . \%$ & $13.4 \%$ & $-9.0 \%$ & $23.7 \%$ & $13.8 \%$ & $-9.9 \%$ & 43.9 & $13.8 \%$ & $-30.1 \%$ & $26.6 \%$ & $17.6 \%$ & $-9.0 \%$ \\
\hline of which: business profits after tax & $20.4 \%$ & $6.6 \%$ & $-13.8 \%$ & $20.0 \%$ & $6.7 \%$ & $-13.3 \%$ & $18.6 \%$ & $6.9 \%$ & $-11.7 \%$ & $61.0 \%$ & $6.9 \%$ & $-54.1 \%$ & $42.1 \%$ & $7.1 \%$ & $-35.0 \%$ \\
\hline of which: personal income after tax & $72.7 \%$ & $87.7 \%$ & $15.0 \%$ & $73.1 \%$ & $87.5 \%$ & $14.4 \%$ & $74.8 \%$ & $87.4 \%$ & $12.6 \%$ & $36.1 \%$ & $87.4 \%$ & $51.3 \%$ & $52.2 \%$ & $80.3 \%$ & $28.2 \%$ \\
\hline of which: regional tax income & $6.9 \%$ & $5.7 \%$ & $-1.2 \%$ & $6.8 \%$ & $5.8 \%$ & $-1.0 \%$ & $6.8 \%$ & $5.8 \%$ & $-1.0 \%$ & $2.8 \%$ & $5.8 \%$ & $3.0 \%$ & $5.8 \%$ & $12.5 \%$ & $6.8 \%$ \\
\hline At system operation stage (JPY/kW) & 9,926 & 12,614 & & 11,917 & 10,616 & & 6,963 & 9,396 & & 24,873 & 56,808 & & 33,639 & 42,004 & \\
\hline RVA as percent revenue from system operation & $25.8 \%$ & $30.0 \%$ & $4.2 \%$ & $33.4 \%$ & $28.1 \%$ & $-5.3 \%$ & $26.8 \%$ & $24.4 \%$ & $-2.4 \%$ & $27.6 \%$ & $31.9 \%$ & $4.3 \%$ & $24.6 \%$ & $20.8 \%$ & $-3.8 \%$ \\
\hline of which: business profits after tax & $70.0 \%$ & $47.1 \%$ & $-22.9 \%$ & $73.9 \%$ & $46.7 \%$ & $-27.2 \%$ & $74.2 \%$ & $46.2 \%$ & $-28.0 \%$ & $62.2 \%$ & $50.3 \%$ & $-11.9 \%$ & $51.8 \%$ & $27.6 \%$ & $-24.2 \%$ \\
\hline of which: personal income after tax & $15.2 \%$ & $32.3 \%$ & $17.1 \%$ & $12.3 \%$ & $31.0 \%$ & $18.7 \%$ & $13.1 \%$ & $28.5 \%$ & $15.4 \%$ & $22.5 \%$ & $30.8 \%$ & $8.3 \%$ & $37.1 \%$ & $61.8 \%$ & $24.7 \%$ \\
\hline of which: regional tax income & $14.8 \%$ & $20.5 \%$ & $5.7 \%$ & $13.8 \%$ & $22.3 \%$ & $8.5 \%$ & $12.7 \%$ & $25.2 \%$ & $12.5 \%$ & $15.3 \%$ & $18.9 \%$ & $3.6 \%$ & $11.1 \%$ & $10.6 \%$ & $-0.5 \%$ \\
\hline
\end{tabular}

*Calculation of regional value-added (RVA) based on primary research data for Japan (in 2012) and from lÖW for Germany (in 2012; data refer to aggregated facility stock for solar installations) (Hirschl B, Heinbach K, Prahl A, Salecki S, Schröder A, Aretz A, Weiß : Wertschöpfung durch Erneuerbare Energien - Ermittlung der Effekte auf Länder- und Bundesebene, forthcoming)/exchange rate: 130JPY/Euro. 
intensity of industries that are involved in activities along the value chain of specific RE technologies. These are obviously only approximations that do not necessarily reflect the RE-specific situation in regard to labor costs and returns. For long-term estimations, such an approach seems justified, because enterprises are unlikely to engage in RE-related activities unless at least industry-average returns are delivered. However, country-specific RErelated policies such as subsidies, quotas, or auction schemes may well impact the economics for specific RE technologies, thereby distorting the modeling results. As Germany and Japan have both adopted similar feed-intariff schemes, the transfer of the IÖW model can be expected to deliver reliable and comparable results. However, it is a subject for further research to test the transferability of the IÖW model to countries with different RE-related policy schemes. This may well require further modifications of the model that take into account these differences in policy frameworks.

Third, the comparative analysis of the regional valueadded revealed a substantial difference in regard to the share of value-added of RE that is captured on the regional level at the stage of planning and construction. Also, German companies generally gain a significant higher share of business profit as compared to their Japanese counterparts at this stage of the RE value chains. A possible root cause for these differences may be that countryspecific industry structures and business practices are not sufficiently reflected in the national, industry-specific statistics. For example, the industry statistics for the construction industry in both countries show a far lower labor ratio in Japan (17.9\%) than in Germany (27.1\%) [47,57]. Taken at face value, this would imply that Japan's construction industry in general employs substantially less direct labor than companies in Germany which seems rather unlikely. Instead, structural differences of the German and Japanese construction industry seem to be a more plausible explanation for these differences. Due to a peculiar licensing system administered by the Ministry of Land, Infrastructure and Transport (MILT), the Japanese construction industry extensively relies on a limited number of general contractors who then subcontract construction work to a multilayered pyramid of first-, second-, and third-tier subcontractors [58-60]. Almost $60 \%$ of all construction work is subcontracted, and about half of all licensed contractors merely act as bidders without performing actual construction work [61]. This multi-layered, subcontracting-based structure of Japan's construction industry is not adequately reflected when applying national industry statistics, because business profits and labor income at the various levels of subcontractors are hidden in the material input costs of the subcontracting top layer firms. As a result, the estimated potential for regional value-added in Japan at the planning and investment stage is most likely understated.
For the case of Japan, it can be concluded that the IÖW model requires further adjustments to better reflect Japan's multi-layered subcontracting structures that are rather common in many Japanese industries. In general, therefore, a careful analysis of the prevailing industry structures is warranted when transferring the IÖW model to other countries.

Fourth, the case of Japan demonstrated that significant adaptations to the IÖW model are necessary in order to incorporate the specific characteristics of a nation's tax system. Differences in national and regional tax schemes have a profound impact on the level and distribution of regional value-added.

Finally, the present IÖW model allows only for an analysis of the direct regional economic effects of RE but does not capture indirect economic effects that are generated across related upstream industries or are induced by additional consumption and investment stimulated in the regional economy. However, it should be possible to couple this model with an I/O analysis to quantify further indirect economic effects generated at upstream value chain stages in the local economy. And by integrating income multipliers, the induced effects of additional consumption or investment can be captured and measured. At the same time, RE may also substitute other economic activities, in particular related to the incumbent, conventional fossil-fuel-based energy sector. In principle, it should be possible to incorporate such substitution effects of RE into the IÖW model by also integrating the value chains of conventional energy sources. In addition to the already noted need for further validation of the IÖW model by means of a systematic comparison with results from other methodological approaches, these final remarks point to possible extensions of the model and directions for further research.

\section{Conclusions}

This analysis has shown that the transfer of the IÖW model to other countries is principally feasible. It, therefore, can be concluded that the regional value-added modeling approach offers a powerful tool for regional planners and policymakers to analyze and capture the potential of RE for regional economies. By applying the approach for a comparative analysis between countries, it can also provide recommendations to enhance the effectiveness of RE-related policies for regional economic development.

Like in Germany, there is a similar promising potential for regional value-added by RE in Japan. However, as the model of regional value-added also allows for a comparison of the economic performance of RE technologies in different countries, it was possible to show that in case of Japan significantly higher total system costs in general, and the balance-of-system costs associated with the 
planning and installation of RE facilities in particular lead to a comparatively weaker economic performance than in Germany despite Japan's rather generous feed-in tariffs. The comparative analysis provided insights into possible structural causes for differences in economic performance, such as high construction and planning costs due to administrative regulations. Further growth of the RE sector in Japan, therefore, may well lead to significant improvements in the economic performance of RE technologies as RE system costs decrease in line with global market developments and as subsequent economies-of-scale raise productivity at the stage of planning and installation as well as at the stage of system operation. In addition, the relaxation of administrative procedures could further shorten the planning cycle in Japan and thereby lead to cost reductions.

The results of the IÖW model for Germany underline the importance of participation by regional players such as local business and farmers, energy cooperatives, or municipality-owned utilities for the generation of regional value-added. Similar to Germany, the results of the comparative regional value-added analysis for Japan show that business profit from RE system operation rather than income from local employment is the most important, long-term source of regional value-added. Therefore, local ownership is essential in order to generate and capture value-added for the region. Similarly, the availability of local capabilities along the various stages of the RE value chains is another important factor that determines the share of value-added captured by the region. While local manufacturing capabilities of RE technologies obviously benefit a local economy, capabilities at the planning and installation stage as well as during system operation including local services for service and finance are an equally important, long-term source of regional value-added. Therefore, when aiming for regional economic development by RE, regional planners and policy makers in Japan should consider policies to encourage or even mandate local investment and ownership as well as local capacity-building [62]. For example, as shown, Japanese municipal and prefectural taxes appropriate a comparatively higher share of regional value-added than in Germany. While higher tax income, especially from the fixed asset tax, may be tempting for local governments in Japan, the comparative analysis suggests that the relatively higher local tax burden in Japan may impede local RE investment. Instead, it seems to be more effective to adopt policies that effectively stimulate local investment into RE technologies, promote regional clusters and value chains in RE, foster local ownership and participation by local citizens, and raise the acceptance for RE by the local community. As a result, the expansion of $\mathrm{RE}$ based on local investment will then also create additional sources for regional tax income.

\section{Endnotes}

${ }^{a}$ The UK government has employed a similar methodological approach referred to as 'supply chain analysis' for Scotland, but the approach focuses on industry turnover and employment and provides little detail in respect to the underlying database.

${ }^{\mathrm{b}}$ The ROE comparison for both countries in the case of large-scale solar installations on land is not fully compatible as the underlying equity ratios differ for both countries (Germany: 50\%/Japan: 30\%). When adjusting the equity ratios, the ROE for Germany increases significantly to about $13 \%$, that is more than twice the level in Japan.

\section{Abbreviations}

kW: kilowatt; MW: megawatt; RE: renewable energy.

\section{Competing interests}

The authors declare that they have no competing interests.

\section{Authors' contributions}

All authors made a significant contribution to the design and adaptation of the IÖW model of regional value-added to the context of Japan, to the comparative analysis of RE economic performance and regional value-added between Japan and Germany. All authors read and approved the final manuscript.

\section{Authors' information}

At the time of our research, Mr. PRAHL was still working as a researcher at the IÖW and contributed to this article in this capacity.

\section{Acknowledgements}

The authors are deeply indebted to the members of the research team at the Institute for Sustainable Energy Policies (ISEP), namely Tetsunari IIDA, Noriaki YAMASHITA, Haruhiko DOHMAN, and Naoki WADA, who diligently compiled the database on technology-specific costs and revenue structures of renewable energy sources in Japan.

\section{Author details}

${ }^{1}$ College of Business Administration, Ritsumeikan University, Kyoto, Japan. ${ }^{2}$ Institute for Sustainable Energy Policies (ISEP), Tokyo, Japan. ${ }^{3}$ Ecologic Institute, Berlin, Germany. ${ }^{4}$ Institute for Ecological Economy Research (IÖW), Berlin, Germany.

Received: 13 August 2014 Accepted: 26 January 2015

Published online: 24 March 2015

\section{References}

1. Renewable Energy Policy Network for the $21^{\text {st }}$ century (REN21) (2014) Renewables 2014 - global status report, Paris. download under http://www. ren21.net/Portals/0/documents/Resources/GSR/2014/GSR2014_full\% 20report_low\%20res.pdf.

2. Renewable Energy Policy Network for the $21^{\text {st }}$ century (REN21) (2013) Renewables - global futures report, Paris. download under http://www. ren21.net/REN21Activities/GlobalFuturesReport.aspx.

3. Rifkin J (2011) The third industrial revolution - how lateral power is transforming energy, the economy, and the world. Palgrave Macmillan, New York

4. International Energy Agency (IEA) (2014) The transformation of power - wind, sun and the economics of flexible power systems. International Energy Agency Bookshop, Paris

5. Bundesministerium für Wirtschaft und Energie (BMWi) (2014) Erneuerbare Energien im Jahre 2013 - Erste vorläufige Daten zur Entwicklung der erneuerbaren Energien in Deutschland auf der Grundlage der Angaben der Arbeitsgruppe Erneuerbare Energien-Statistik (AGEE-Stat). download under

6. Stablo J, Ruppert-Winkel C (2012) The integration of energy conservation into the political goal of renewable energy self-sufficiency - a German case study based on a longitudinal reconstruction. Sustainability 5:888-916 
7. Klagge B, Brocke T (2011) Decentralized electricity production from renewable sources as a chance for local economic development ? Qualitative study of two pioneer regions in Germany. In: Schäfer M, Kebir N, Philipp D (eds) Micro perspectives for decentralized energy supply. Proceedings of the International Conference Technische Universität Berlin, Universitätsverlag TU Berlin, Berlin, pp 21-26

8. Wuppertal Institut für Klima, Umwelt, Energie (2013) StadtwerkeNeugründungen und Rekommunalisierungen. Energieversorgung in kommunaler Verantwortung, Wuppertal, download under http://wupperinst. org/uploads/tx_wupperinst/Stadtwerke_Sondierungsstudie.pdf

9. Ministry of Economy, Trade, and Industry (METI) (2014) Basic energy plan, Tokyo (Keizai Sangyōshō, enerugi- kihon keikaku). download under http://www. enecho.meti.go.jp/category/others/basic_plan/pdf/140411.pdf (in Japanese)

10. Institute for Sustainable Energy Policies (ISEP) (2014) Renewables Japan status report - executive summary, Tokyo: download under http://www. isep.or.jp/en/wp-content/uploads/2014/07/JSR2014_Summary_EN.pdf

11. Furuya S (2013) Community power plants. Ippanshoshinsho, Tokyo, komyuniti- hatsudenshō) (in Japanese).

12. Takahashi M (2012) Starting the renewable energy revolution - regional community-based energy. Ōtsuki Shōten, Tokyo, Sheen energy kakumei-wo hajimeyo - chiiki-de tsukuru mina-no denryoku)., (in Japanese)

13. Kurasaka H (2013) Local economic impacts of renewable energies, Proceedings at the Annual Meeting of the Society for Environmental Economics and Policy Studies (SEEPS) at Kobe, September 21/22, 2013 (Saiseikanō enerugi- dōnyū-ni yoru chiiki keizai kōka-ni tsuite). download under http://www.seeps.org/ meeting/2013/submit/abst/2140_hr3Rsyfs.doc (in Japanese)

14. Breitschopf B, Nathani C, Resch G (2011) Review of approaches for employment impact assessment of renewable energy deployment, IEA-Renewable Energy Technology Deployment: download under http://publica.fraunhofer.de/eprints/ urn:nbn:de:0011-n-1988024.pdf.

15. Miller R, Peter D (2009) Input-output analysis, foundations and extensions. Cambridge University Press, Cambridge

16. Loveridge S (2004) A typology and assessment of multi-sector regional economic impact models. In: Regional Studies, Vol. 38/3. Routledge, London, pp 305-317

17. Lehr U, Breitschopf B, Lutz C, Edler D, O'Sullivan M, Nienhaus K, Nitsch J, Bickel P, Ottmüller M (2011) Kurz- und langfristige Arbeitsplatzwirkungen des Ausbaus der erneuerbaren Energien auf den deutschen Arbeitsmarkt. Fraunhofer-Institut für Innovation- und Systemforschung, Osnabrück

18. O'Sullivan M, Edler D, Bickel P, Lehr U, Frank P, Sakowski F (2013) Bruttobeschäftigung durch erneuerbare Energien in Deutschland im Jahr 2012 - eine erste Abschätzung. Gesellschaft für Wirtschaftliche Strukturforschung $\mathrm{mbH}$, Osnabrück

19. Spanish Renewable Energy Association (APPA) (2009) Study of the macroeconomic impact of renewable energies in Spain. http://www.appa. es/descargas/Informe_APPA_ENGLISH.pdf.

20. National Institute of Science and Technology Policy (NISTEP) (2013) Economic and environmental impact analysis for construction of renewable energy power plants by extended Input-output table, Discussion Paper No. 96, Tokyo (kakuchō sangyō kanrenhyō-ni yoru saiseikanō enerugi-hatsudennshisetsu no keizai kankyō-he no hakkyūkōka bunseki). download under http://data.nistep.go. jp/dspace/bitstream/1 1035/2419/1/NISTEP-DP096-FullJ.pdf (in Japanese).

21. Coon R, Hodur N, Bangsund D (2012) Renewable energy industries' contribution to the North Dakota economy, In: Agribusiness and Applied Economics, 702. download under http://ageconsearch.umn.edu/bitstream/ 140122/2/AAE702.pdf.

22. Allan G, McGregor P, Swales K (2011) The importance of revenue sharing for the local impacts of a renewable energy project - a social accounting matrix approach. In: Regional Studies, vol. 45/9. Routledge, London, pp 1171-1186

23. Heinbach K, Aretz A, Hirschl B, Prahl A, Salecki S (2014) Renewable energies and their impact on local value-added and employment. Energy, Sustainability and Society 4(1):1-10

24. Flegg A, Thomo T (2010) Regional input-output tables and the FLQ formula: A case study of Finland. Regional Studies Association Annual International Conference 2010: Regional Responses and Global Shifts: Actors, Institutions and Organisations, Pecs, Southern Hungary, 24-26 May 2010, University of the West of England, Bristol. download under http://eprints.uwe.ac.uk/12338/.

25. Hirschl B, Aretz A, Prahl A, Böther T, Heinbach K, Pick D, Funcke S (2010) Kommunale Wertschöpfung durch Erneuerbare Energien, Schriftenreihe des Institut für Ökologische Wirtschaftsforschung (IÖW 196/10);Berlin.
26. Kosfeld R, Gückelhorn F (2012) Ökonomische Effekte erneuerbarer Energien auf regionaler Ebene. Raumforsch Raumordn 70:437-449

27. Institut für angewandtes Stoffmanagement (IfaS), Deutsche Umwelthilfe e.V. (DUH) (2013) Kommunale Investitionen in Erneuerbare Energien - Wirkungen und Perspektiven. download under http://www. stoffstrom.org/fileadmin/userdaten/dokumente/Veroeffentlichungen/ 2013-04-04_Endbericht.pdf.

28. Hoppenbrook C, Albrecht AK (2009) Diskussionspapier zur Erfassung der regionaler Wertschöpfung in 100\%-EE-Regionen, In: DEENET (Hrsg.), Arbeitsmaterialien 100EE, Nr. 2: download under http://www.100-ee.de/index. php?id=schriftenreihe\&no_cache=1.

29. Bundesministerium für Verkehr, Bau und Stadtentwicklung (BMVBS) (2011) Strategische Einbindung regenerativer Energien in regionale Energiekonzepte - Wertschöpfung auf regionaler Ebene. download under http://www.bbsr.bund.de/BBSR/DE/Veroeffentlichungen/BMVBS/Online/ 2011/ON232011.html?nn=423048.

30. Raupach-Sumiya J (2014) Measuring regional economic value-added of renewable energy - the case of Germany. In: Shakai Shisutemu Kenkyū (Social System Study), Vol. 29. Ritsumeikan University BKC Research Organization of Social Sciences Kyoto pp 1-31 download under http://www.ritsumei.ac.jp/acd/re/ssrc/result/memoirs/kiyou29/29-01.pdf.

31. Department of Trade and Industry (2004) Renewable supply chain gap analysis. Department of Trade and Industry, London

32. Matsumoto N, Hondo H (2011) Analysis on employment effects of the introduction of renewable energy technologies using an extended input-output table. J Japan Institute of Energy (Nihon Enerugi- Gakkai) 90:258-267, Kakuchōsangyōkanrenhyō-wo riyō shita saiseikanō enerugi- dōnyū-no koyōkōka bunseki) (in Japanese)

33. Ishikawa Y, Nakamura R, Matsumoto A (2012) Economic effects of the introduction of renewable energy in the Tohoku region - analysis of the introduction of solar and wind power based on interregional input-output tables, RIETI Policy Discussion Series 12-P-014. Research Institute of Economy, Trade and Industry, Tokyo, Töhokuchiiki-ni okeru saiseikanō enerugi-dōnyū-no keizaikōka - chiikikansangyōkannrenhyōni yoru taiyōkōhatsuden füryokuhatsudendōnyū-no bunseki) (in Japanese)

34. Nakazawa $\mathrm{R}$, Nakazawa J, Matsumoto A (2012) Economic and $\mathrm{CO}_{2}$ reduction effects by wood-fed biomass - construction and new application of a regional I/O model. In: Chiikigaku Kenkyū (Studies in Regional Science), Vol. 42/4. The Japan Section of the Regional Science Association International, Tokyo, pp 799-817, Kishitsu baiomasu-wo katsuyōshita $\mathrm{CO}_{2}$ sakugen-to chiikikeizaikōka - Chiikisangyōkanren moderu-no kōchiku-to aratana tekiyō) (in Japanese).

35. Hienuki S, Hondo H (2012) Employment life cycle analysis of geothermal power generation using an extended input-output table. In: Proceedings of the $28^{\text {th }}$ Conference on Energy Systems, Economy and Environment by the Japan Society of Energy and Resources (Enerugi- Shigen Gakkai), January $30^{\text {th }} \sim 31^{\text {st }}$, 2012. Japan Society of Energy and resources, Osaka, pp 209-212, Kakuchōchōsangyoukanrenhyō-wo mochiita chinetsuhatsuden-no raifusaikuru koyōbunseki) (in Japanese).

36. Shimomura S, Nakazawa J, Matsumoto A (2013) Regional economic effects of introducing solar power generation system applying extended regional I/O analysis - A comparative evaluation of different business forms in Kochi prefecture, paper presented at the 50th annual meeting of the Japan Section of the Regional Science Association International (JSRSAI), October $12 \sim 14$ th, 2013 at Tokushima University, (Kankyōsangyōbunsekiyōchiikisangyōkanrenhyō-wo mochiita taiyōkōhatsuden-no chiikikeizaikōka - Köchiken-ni okeru jigyōkeitai-ni yoru kōka-no hikakubunseki) (in Japanese).

37. Cost Evaluation Committee of the Energy / Environment Conference (2011) Report of the Cost Evaluation Committee, December 19 $9^{\text {th }}, 2011$, Tokyo (Kosuto-nado hyōkaiinkai enerugi- kankyō kaigi, kosuto-nado hyōkaïnkaihyōkokushō). download under http://www.cas.go.jp/jp/seisaku/npu/policy09/pdf/20111221/ hokoku.pdf (in Japanese).

38. METI Evaluation Committee (Ministry of Economy, Trade and Industry Agency for Natural Resources and Energy, Evaluation Committee on Procurement Prices) (2012) Recommendations regarding tariffs and FIT period for 2012, April $27^{\text {th }}, 2012$ (Keizai Sangyōshō Chōtatsu Kakakutō Santeiiinkai, Heisei 24 nendo chōtatsukakaku oyobi chōtatsukikan-ni kansuru iken). down load under http://www.meti.go.jp/committee/chotatsu_kakaku/report_001.html.

39. METI Evaluation Committee (Ministry of Economy, Trade and Industry Agency for Natural Resources and Energy, Evaluation Committee on Procurement Prices) (2013) Recommendations regarding tariffs and FIT period for 2013, 
March $11^{\text {th }}, 2013$ (Keizai Sangyōshō Chōtatsu Kakakutō Santeiïnkai, Heisei 24 nendo chōtatsukakaku oyobi chōtatsukikan-ni kansuru iken) download under http://www.meti.go.jp/committee/chotatsu_kakaku/pdf/report_002_01_00.pdf

40. Energy New Industrial Technology Development Organization (NEDO) (2014) NEDO renewable energy technology whitebook, 2nd edn. NEDO, Morikita Shuppan, Tokyo, saiseikanō enerugi- gijutsu hakusho daizban (in Japanese)

41. Japan Renewable Energy Foundation (JREF) (2013) The state of the solar power business and cost 2013, Tokyo (Taiyōkōhatsudeniigyō to kosuto 2013). download under http://jref.or.jp/images/pdf/20131220/reports_20131220.pdf (in Japanese).

42. Japan Renewable Energy Foundation (JREF) (2013) Present state and analysis of the cost of wind power generation in Japan, Discussion Paper, Tokyo (Nihon no rikujöfüryokuhatsuden kosuto no genjō to bunseki): download under http://jref.or.jp/activities/reports_20131023.php (in Japanese).

43. Public Electric Utility Business Association (2012) Requests related to the Feed-In-Tariff System for hydro power, April $3^{\text {rd }}, 2012$, Tokyo (Köeidenkijigyōkeieishakaigi, Suiryokuhatsuden-no zenryōkaitoriseido-ni kansuru yōbō). download under http://www.meti.go.jp/committee/chotatsu_ kakaku/pdf/004_03_00.pdf (in Japanese).

44. National Small-Scale Hydro Promotion Committee (2012) Requirements for the expansion of small-scale hydro power under the FIT system, April $3^{\text {rd }}, 2012$ (Zenkoku shōsuiryokuriyōsokushinkyōgikai, FIT-ni yoru shōsuiryokuhatsudenkakudaino jōken). download under http://www.meti.go.jp/committee/chotatsu_kakaku/ pdf/004_04_00.pdf (in Japanese).

45. Japan Wind Power Association (2012) Materials provided for the $3^{\text {rd }}$ Meeting of the Evaluation Committee, March 19 ${ }^{\text {th }}, 2012$, Tokyo (Nihonfüryokuhatsudenkyōkai, Daißkai chōtatsukakakutōsannteiiinikai gosetsumeishiryō). Download under http://www.meti.go.jp/committee/ chotatsu_kakaku/003_05_00.pdf (in Japanese).

46. Japan Project Industry Council (2013) About the cost estimate for wood-fed biomass, Tokyo, (JAPIC Shinrinsaiseijigyōkaiinkai, Shinrinbaiomasuhatsuden kosuto-ni tsuite). download under http://www.japic.org/report/pdf/national_strategy_ group30.pdf (in Japanese).

47. Homepage of the Japanese Ministry of Finance (MOF), access on 23.6.2014 http://www.mof.go.jp/english/pri/reference/ssc/index.htm.

48. Website of New Energy Foundation, Database of Renewable Energy Research Organizations \& Companies in East Asia. http://jrdb.asiabiomass.jp/index.php? lang=en access on December 28 $8^{\text {th }}, 2014$.

49. Homepage of the Japanese Ministry of Internal Affairs and Communications (MIAC), access on 23.6.2014. http://www.soumu.go.jp/main_sosiki/jichi_zeisei/ czaisei/czaisei_seido/ichiran01.html.

50. KPMG Taxation Corporation (2012) Taxation in Japan 2012, Tokyo: download under.

51. National Tax Agency (NTA) (2011) The $137^{\text {th }}$ National Tax Agency Annual Statistics Report FY2011, Tokyo, p. 12 (Dai 137kai kokuzeichō tōkeinenpō heisei 23 nendōban). download under http://www.nta.go.jp/kohyo/tokei/ kokuzeicho/minkan2012/pdf/001.pdf (in Japanese).

52. METI Evaluation Committee (Ministry of Economy, Trade and Industry Agency for Natural Resources and Energy, Evaluation Committee on Procurement Prices) (2014) Presentation materials distributed in $15^{\text {th }}$ committee meeting on March $7^{\text {th }}, 2014$ (Keizai Sangyōshō Chōtatsu kakakutō Santeiiinkai). down load under http://www.meti.go.jp/committee/ chotatsu_kakaku/pdf/015_s02_00.pdf, http://www.meti.go.jp/committee/ chotatsu_kakaku/pdf/015_s03_00.pdf, (in Japanese).

53. International Renewable Energy Agency (IRENA) (2013) Renewable power generation costs in 2012. An overview: download under http://www.irena. org/DocumentDownloads/Publications/Overview_Renewable\%20Power\% 20Generation\%20Costs\%20in\%202012.pdf.

54. Seel J, Barbose GL, Wiser RH (2013) Why are residential PV prices in Germany so much lower than in the United States? A scoping analysis, presentation, Lawrence Berkeley National Laboratory. download under http://eetd.lbl.gov/node/50173.

55. METI Evaluation Committee (Ministry of Economy, Trade and Industry Agency for Natural Resources and Energy, Evaluation Committee on Procurement Prices) (2014) Presentation materials distributed in $15^{\text {th }}$ committee meeting on March $7^{\text {th }}, 2014$ (Keizai Sangyōshō Chōtatsu kakakutō Santeiiinkai). down load under http://www.meti.go.jp/committee/ chotatsu_kakaku/pdf/015_s02_00.pdf.

56. EU-Japan Centre for Industrial Cooperation (2014) The clean energy sector in Japan - An analysis on investment and industrial cooperation opportunities for EU SMEs, Tokyo. download under http://www.eu-japan.eu/sites/eu-japan.eu/files/ clean-energy-paper-27feb-finale.pdf\#search='clean+technology+in+Japan+EU.
57. Homepage of the Deutsche Bundesbank, access on 23.6.2014 http://www. bundesbank.de/Navigation/DE/Statistiken/Unternehmen_und_private_ Haushalte/Unternehmensabschluesse/Tabellen/tabellen.html.

58. Homepage of Ministry of Infrastructure, Land and Transport (MILT), access on 23.6.2014 http://www.mlit.go.jp/sogoseisaku/const/kengyo/kyoka-e.htm.

59. Japan Federation of Construction Contractors (JFCC) (2013) Construction industry handbook 2013 (Kensetsugyō handobukku 2013) download under http://www.nikkenren.com/publication/handbook.html.

60. Research Institute of Construction and Economy (RICE) (2007) The structure of the construction industry and its contribution to society, No. 49, October 2007, Tokyo, (Kensetsukeizaikenkyūjo, Kensetsusangyō-no kōzō to shakai-he no kōken, kensetsukeizai ripōto). download under http://www.rice.or.jp/ regular_report/construction_economic_report.html (in Japanese).

61. The Economist (2001) Japan's construction industry - pass the scaffolding, print edition, July $12^{\text {th }}$. The Economist Newspaper Limited, London, download under: www.economist.com/node/693543

62. Wada T, Toyota $Y$, Taura K, Ito S (2014) Establishing energy cooperatives by citizens and communities (shimin chiiki kyödōhatsudensho no tsukurikata). Shin Nippon Press. 168-170. in Japanese.

\section{Submit your manuscript to a SpringerOpen ${ }^{\odot}$ journal and benefit from:}

- Convenient online submission

- Rigorous peer review

- Immediate publication on acceptance

- Open access: articles freely available online

- High visibility within the field

- Retaining the copyright to your article

Submit your next manuscript at $>$ springeropen.com 